\title{
Analysis of The Efficiency In $\mathrm{Sb}_{2} \mathrm{Se}_{3}$ Thin-Film Solar Cells Using Alternative Buffer Layers In n-p and n-i-p Structures By Numerical Simulation.
}

F Ayala-Mato ( $\sim$ fayala840425@gmail.com )

Universidad Autónoma del Estado de Morelos https://orcid.org/0000-0003-4243-9014

0 Vigil-Galán

IPN ESFM: Instituto Politecnico Nacional Escuela Superior de Fisica y Matematicas

Maykel Courel

Universidad de Guadalajara - Centro Universitario de Valles

M. M. Nicolás-Marín

IPN ESFM: Instituto Politecnico Nacional Escuela Superior de Fisica y Matematicas

\section{Research Article}

Keywords: Sb2Se3, solar cells, ETL, n-p and n-i-p structures, a simulation study

Posted Date: June 29th, 2021

DOl: https://doi.org/10.21203/rs.3.rs-644062/v1

License: (c) (i) This work is licensed under a Creative Commons Attribution 4.0 International License.

Read Full License 


\section{Abstract}

Antimony Sulfide $\left(\mathrm{Sb}_{2} \mathrm{Se}_{3}\right)$ Solar Cells are considered a promising emerging photovoltaic devices technology. However, the best reported experimental efficiency $(9.2 \%)$ is well below the theoretical limit of $30 \%$. In this research is demonstrated, by numerical simulation, that using different buffer or electron transport layers (ETL) and device structures (n-p or n-i-p) can significantly increase the solar cell performance. The study is based on two underlying considerations: the use of inorganic materials to facilitate the manufacturing process and the analysis of the simulation parameters that adjust to the experimental conditions in which the cells can be processed. In the n-p structures, the use of single layers and bilayers as ETL was evaluated and the possible mechanism that explain the electrical parameters of the solar cell were discussed. Especial attention was made in the role of interfacial state density and band alignment in the $\mathrm{ETL} / \mathrm{Sb}_{2} \mathrm{Se}_{3}$ interface. In addition, the n-i-p structure was studied by adding a hole transport layer $(\mathrm{HTL})$. An improvement in open circuit voltage (Voc) is observed compared with $n-p$ structure. Finally, the behavior of Voc and efficiency vs thickness of the ETL and $\mathrm{Sb}_{2} \mathrm{Se}_{3}$ layers was analyzed. The results show that using alternative ETLs a significant improve in Voc and efficiency could be achieved for $n-p$ and n-i-p structures. After thickness optimization and taking account a moderate interface defect density, values of Voc and efficiency higher than $600 \mathrm{mV}$ and $15 \%$ were respectively obtained.

\section{Introduction}

The antimony chalcogenides family $\mathrm{Sb}_{2}\left(\mathrm{~S}_{1-\mathrm{x}} \mathrm{Sex}\right)_{3}$ has been used as a promising absorber material in planar heterojunction or sensitized solar cells. In particular, the $\mathrm{Sb}_{2} \mathrm{Se}_{3}$ compounds has been considered an attractive material in the development of second-generation solar cells in thin-film technology. It is made up of non-toxic elements with relative abundance, with an adequate bandgap value of $1.12 \mathrm{eV}$, a high absorption coefficient, and p-type conductivity. It is considered as one-dimensional material with the electron density confined in ribbons $\left(\mathrm{Sb}_{4} \mathrm{Se}_{6}\right) \mathrm{n}$, with electrically benign grain boundaries in the [001] direction, particularly favorable in flexible devices, due to the high tolerance to deformation. It presents an excellent physicochemical stability and low melting point $\left(611^{\circ} \mathrm{C}\right)$ with high vapor pressure that allows the synthesis of high-quality films at relatively low temperatures [1]. Despite these excellent properties, the record efficiencies of $7.5 \%$ [2] and 9.2\% [3] for $n-i-p$ and n-p structures respectively, are well below the theoretical limit of $30 \%$. Several aspects must be considered in order to improve the performance in this type of solar cells. The so-called Voc deficit stands out, which according to the detailed balance principle should be approximately $0.24 \mathrm{~V}$ for a bandgap about $1.0 \mathrm{eV}$. The $\mathrm{Voc}$ deficit in the record $\mathrm{Sb}_{2} \mathrm{Se}_{3}$ based solar cells is greater than $0.7 \mathrm{~V}$ [3], which is worse than those of the CIGS $(0.42 \mathrm{~V}), \mathrm{CdTe}(0.59 \mathrm{~V})$ and CZTSSe $(0.62 \mathrm{~V})$. The most important factors that affect the Voc in these solar cells are the interfaces and bulk absorber recombination and the low free carrier concentration [4]. On the other hand, the orientation of the ribbons also plays an important role in the solar cell performance. The ribbons growing perpendicular to the substrate decreases grain boundary effects favoring the carrier transport. 
In the processing of the $\mathrm{Sb}_{2} \mathrm{Se}_{3}$ solar cells different routes have been experimentally proposed to improve the device power conversion: different structures and configurations, different deposition techniques and the use of different buffer or ETL and HTL layers in the n-p and n-i-p structures [5]. An important aspect to considerer when new materials are proposed is to avoid the use of organic compounds. Although, in solar cells such as perovskites have given good results [6] and the record efficiency for $\mathrm{Sb}_{2}\left(\mathrm{~S}_{1-\mathrm{x}} \mathrm{Sex}\right)_{3}$ based solar cells is obtained using an organic HTL[7]; a poor stability and potential difficulties in processing on an industrial scale, may limit the use of these materials in photovoltaic applications. Therefore, the study to introduce inorganic layers in the processing of solar cells will be the goal in this work.

Several experimental reports can be found in literature: $C d_{1-x} Z n_{x} S$ was proposed as an alternative buffer layer to CdS [8]; modifying the band alignment in the $\mathrm{Cd}_{1-x} \mathrm{Zn}_{\mathrm{x}} \mathrm{S} / \mathrm{Sb}_{2} \mathrm{Se}_{3}$ interface and increasing the efficiency. Randomly oriented $\mathrm{ZnO}$ showed that induces the growth of $\mathrm{Sb}_{2} \mathrm{Se}_{3}$ film with preferred [221] orientation, which results in fewer defects at the interface improving device efficiency [9]. CdSe has been integrated into $\mathrm{Sb}_{2} \mathrm{Se}_{3}$ solar cells replacing the $\mathrm{CdS}$ with an increase in the efficiency from $4.16 \%$ with CdS to $4.51 \%$ with CdSe [10]. In these works, the solar cells were made in n-p structure in substrate or superstrate configuration. In simulation studies, where new materials are studied, the greatest emphasis has been placed on n-i-p type structures and focused especially on HTLs with CdS as ETL. In [11] the authors analyze the impact of different HTL in efficiency and concluding that $\mathrm{CuO}$ has the best performance, reporting a final efficiency after parameter optimization of $16.15 \%$. On the other hand, Cao et al. [12] shown that an inverted configuration in n-i-p structure and using $\mathrm{NiO}$ as HTL could improve the efficiency reporting a value of $24.7 \%$ in ideal conditions, i.e. negligible defect states in the $\mathrm{Sb}_{2} \mathrm{Se}_{3}$ layer and interface $\mathrm{HTL} / \mathrm{Sb}_{2} \mathrm{Se}_{3}$. A power conversion efficiency of $29.35 \%$ was calculated in [13] by the addition of the $\mathrm{BaSi}_{2}$ as a back-surface layer and CdS as ETL in the Al/FTO/CdS/ $\mathrm{Sb}_{2} \mathrm{Se}_{3} / \mathrm{BaSi}_{2} / \mathrm{Mo}$ configuration. Efficiency values of $20 \%$ or higher in this type of solar cells, based on simulation models, should be analyzed with caution. Sometimes the calculations overestimate some parameters of the solar cells that are entered as "optimized parameters". However, these studies allow to evaluate the impact of new layers and structures on solar cells performance.

Recently, the authors have studied the impact on the efficiency of $\mathrm{Sb}_{2} \mathrm{Se}_{3}$ solar cells, replacing CdS with $\mathrm{Cd}_{1-\mathrm{x}} \mathrm{Zn}_{\mathrm{x}} \mathrm{S}$ in n-i-p structures [14]. In the simulation process the parameters were carefully selected in order to obtain an approach as realistic as possible. Two configurations were evaluated: the superstrate $\mathrm{AZO} / \mathrm{Cd}_{1-\mathrm{x}} \mathrm{Zn}_{\mathrm{x}} \mathrm{S} / \mathrm{Sb}_{2} \mathrm{Se}_{3} / \mathrm{HTL}$ and inverted $\mathrm{HTL} / \mathrm{Sb}_{2} \mathrm{Se}_{3} / \mathrm{Cd}_{1-\mathrm{x}} \mathrm{Zn}_{\mathrm{x}} \mathrm{S} / \mathrm{AZO}$, with $\mathrm{Cu}_{2} \mathrm{O}$ as HTL. The impact of molar composition of the ternary compound together with the $\mathrm{ETL}$ and $\mathrm{Sb}_{2} \mathrm{Se}_{3}$ parameters layers were investigated. The best result was obtained in the superstrate configuration with final efficiency of $16 \%$ after parameters optimization.

Taking in mind the efforts to boost the power conversion efficiencies of solar cells based on antimony chalcogenide compounds, in this work is presented a numerical simulation of $\mathrm{Sb}_{2} \mathrm{Se}_{3}$ solar cells with $\mathrm{p}-\mathrm{n}$ and $n$-i-p structures. The emphasis will be centered in the buffer layer or ETL using inorganic materials. A solar cell with CdS as buffer layer in n-p structure is used as reference cell. The $\mathrm{CdSe}, \mathrm{ZnO}, \mathrm{V}_{2} \mathrm{O}_{5}$, and 
bilayers formed by some of these compounds are evaluated as alternative candidates to the CdS. Finally adding a layer $\mathrm{Cu}_{2} \mathrm{O}$ as $\mathrm{HTL}$ the $\mathrm{n}$-i-p structure is analyzed. The roll of lattice mismatch, interface states, the band alignment, and the thickness of the buffer (or ETL) and absorber layers will be also discussed.

\section{Structures And Device Simulation Parameters}

The structures studied in this work are shown in Fig. 1. The numerical simulation of the $\mathrm{Sb}_{2} \mathrm{Se}_{3}$ solar cells was performed using SCAPS [15]. Performance parameters are obtained by solving Poisson's equation, electron continuity equation, and continuity equation, as previously described [14]. Table 1 summarize the semiconductor layer parameters and Table 2 those related to the interfaces.

Table 1. Semiconductor parameters for each layer used in the simulation.

\begin{tabular}{|c|c|c|c|c|c|c|c|c|}
\hline \multirow{2}{*}{ Parameters } & \multicolumn{2}{|c|}{ TCO } & \multicolumn{4}{|c|}{ Buffer layers/ETL } & \multirow{2}{*}{\begin{tabular}{|c|} 
Absorbe \\
$\mathbf{r}$ \\
$\mathrm{Sb}_{2} \mathrm{Se}_{3}$ \\
\end{tabular}} & \multirow{2}{*}{$\begin{array}{c}\mathrm{HTL} \\
\mathrm{Cu}_{2} \mathrm{O}\end{array}$} \\
\hline & FTO & AZO & $\mathrm{ZnO}$ & $\mathrm{V}_{2} \mathrm{O}_{5}$ & Case & $\mathrm{CdS}$ & & \\
\hline$d(\mu \mathrm{m})$ & 0.2 & 0.2 & 0.1 & 0.1 & 0.1 & 0.1 & 0.5 & 0.05 \\
\hline$E_{g}(e V)$ & 3.6 & 3.3 & 3.3 & Variable & 1.7 & 2.42 & 1.20 & 2.1 \\
\hline $\mathrm{X}_{e}(\mathrm{eV})$ & 4.4 & 4.5 & 4.4 & 3.99 & 4.2 & 4.5 & 4.15 & 3.2 \\
\hline$\varepsilon_{r}$ & 9 & 9 & 9 & 4.28 & 10.6 & 10 & 14.38 & 7 \\
\hline $\mathrm{N}_{\mathrm{c}}\left(\mathrm{cm}^{-3}\right)$ & $2.2 \times 10^{18}$ & $2.2 \times 10^{18}$ & $2.2 \times 10^{18}$ & $2.2 \times 10^{18}$ & $2.2 \times 10^{18}$ & $2.2 \times 10^{18}$ & $2.2 \times 10^{18}$ & $2.2 \times 10^{18}$ \\
\hline $\mathrm{N}_{\mathrm{v}}\left(\mathrm{cm}^{-3}\right)$ & $1.8 \times 10^{19}$ & $1.8 \times 10^{19}$ & $1.8 \times 10^{19}$ & $1.8 \times 10^{19}$ & $1.8 \times 10^{19}$ & $1.8 \times 10^{19}$ & $1.8 \times 10^{19}$ & $1.8 \times 10^{19}$ \\
\hline$v_{t h_{-} e}(\mathrm{~cm} / \mathrm{s})$ & $10^{7}$ & $10^{7}$ & $10^{7}$ & $10^{7}$ & $10^{7}$ & $10^{7}$ & $10^{7}$ & $10^{7}$ \\
\hline$v_{t h_{-} h}(\mathrm{~cm} / \mathrm{s})$ & $10^{7}$ & $10^{7}$ & $10^{7}$ & $10^{7}$ & $10^{7}$ & $10^{7}$ & $10^{7}$ & $10^{7}$ \\
\hline$\mu_{\mathrm{e}}\left(\mathrm{cm}^{2} / \mathrm{Vs}\right)$ & 33 & 50 & 50 & 126 & 100 & 100 & 17 & 3 \\
\hline$\mu_{\mathrm{h}}\left(\mathrm{cm}^{2} / \mathrm{Vs}\right)$ & 8 & 25 & 25 & 34 & 25 & 25 & 2.6 & 10 \\
\hline $\mathrm{N}_{D}\left(\mathrm{~cm}^{-3}\right)$ & $10^{18}$ & $10^{20}$ & $10^{18}$ & $10^{18}$ & $10^{17}$ & $10^{17}$ & - & - \\
\hline $\mathrm{N}_{\mathrm{A}}\left(\mathrm{cm}^{-3}\right)$ & - & - & - & - & - & - & $10^{14}$ & $10^{18}$ \\
\hline $\mathrm{N}_{\mathrm{t}}\left(\mathrm{cm}^{-3}\right)$ & $10^{17}$ & $10^{17}$ & $10^{17}$ & $10^{16}$ & $10^{16}$ & $10^{16}$ & $10^{15}$ & $10^{17}$ \\
\hline Abs. coef. & [16] & [17] & [17] & [19] & [17] & [17] & [1] & [20] \\
\hline
\end{tabular}

${ }^{*}$ indirect band gap: $\mathrm{Eg}=2.16 \mathrm{eV}$ and direct band gap: $\mathrm{Eg}=2.64 \mathrm{eV}$

Table 2. Interface parameters 


\begin{tabular}{|c|c|c|}
\hline Parameter & Buffer layer-ETL/Sb2Se3 & HTL/ Sb2Se3 \\
\hline$\sigma_{e}\left(\mathrm{~cm}^{2}\right)$ & $10^{-15}$ & $10^{-15}$ \\
\hline$\sigma_{h}\left(\mathrm{~cm}^{2}\right)$ & $10^{-15}$ & $10^{-15}$ \\
\hline $\mathrm{N}_{\mathrm{t}}\left(\mathrm{cm}^{-2}\right)$ & $10^{15}$ & $10^{15}$ \\
\hline Position for energy level & Middle of the interface bad gap & Middle of the interface bad gap \\
\hline Energetic distribution & Single & Single \\
\hline Type of defect & Neutral & Neutral \\
\hline
\end{tabular}

\section{Considerations about the influence of lattice mismatch on interface defect density.}

Lattice mismatch between two different crystals is an important factor to consider in the solar cell design. The differences in crystallographic structures and lattice constants are the principal cause, but not the only one, in defect formation at the interfaces. The lattice mismatch is expressed as [21]:

$$
f=\frac{2\left(a_{1}-a_{2}\right)}{a_{1}+a_{2}}
$$

Where $a_{2}$ and $a_{1}$ are the lattice parameters of the substrate film and the film deposited on the substrate, respectively. The deposited film is in expansion if $f>0$ or in tension if $f<0$.

Increasing the absolute value of $f$ determines a higher density of states in the metallurgical interface. The $\mathrm{Sb}_{2} \mathrm{Se}_{3}$ has orthorhombic structure with $a=11.7 \AA, b=3.6 \AA$ and $c=11.6 \AA$. The values of lattice mismatch are shown in Table 3.

Table 3. Lattice mismatch between the interfaces of the simulated solar cells

\begin{tabular}{|l|l|c|c|}
\hline \multicolumn{1}{|c|}{ Interface } & \multicolumn{1}{|c|}{ Crystal structure } & $\begin{array}{c}\text { Lattice parameters } \\
\text { of ETL }(\boldsymbol{\AA})\end{array}$ & $\begin{array}{c}\text { Lattice } \\
\text { mismatch f }\end{array}$ \\
\hline $\mathrm{CdS} / \mathrm{Sb}_{2} \mathrm{Se}_{3}$ & Hexagonal/Orthorhombic & $a=4.2$ & 94.3 \\
\hline $\mathrm{CdSe} / \mathrm{Sb}_{2} \mathrm{Se}_{3}$ & Hexagonal/Orthorhombic & $a=4.3$ & 92.5 \\
\hline $\mathrm{ZnO} / \mathrm{Sb}_{2} \mathrm{Se}_{3}$ & Hexagonal/Orthorhombic & $a=3.2$ & 114.1 \\
\hline $\mathrm{V}_{2} \mathrm{O}_{5} / \mathrm{Sb}_{2} \mathrm{Se}_{3}$ & Orthorhombic/Orthorhombic & $a=11.51$ & 1.6 \\
\hline $\mathrm{Sb}_{2} \mathrm{Se}_{3} / \mathrm{Cu}_{2} \mathrm{O}$ & Orthorhombic/cubic & $a=4.27$ & -93.1 \\
\hline
\end{tabular}

As can be seen the lowest lattice mismatch is obtained for the $\mathrm{V}_{2} \mathrm{O}_{5} / \mathrm{Sb}_{2} \mathrm{Se}$, which will be analyzed later

\section{Results And Discussion}

4.1 Effect of different TCOs and different single-layers on n-p device photovoltaic performance. 
In the first step, the FTO and ZnO as TCOs with different single buffer layers were studied.

Table 4 shows the electrical parameters of the $\mathrm{Sb}_{2} \mathrm{Se}_{3}$ solar cells whose configurations are shown in Figure $1 \mathrm{a}), \mathrm{b}), \mathrm{c}$ ) and d).

Table 4. Electrical parameters for solar cells in n-p structures with different TCOs and buffer layers

\begin{tabular}{|lllll|}
\hline Device structure (p-n configuration) & $\begin{array}{l}\text { Voc } \\
(\mathrm{mV})\end{array}$ & $\mathrm{Jsc}\left(\mathrm{mA} / \mathrm{cm}^{2}\right)$ & $\mathrm{FF}(\%)$ & $(\%)$ \\
\hline $\mathrm{FTO} / \mathrm{CdS} / \mathrm{Sb}_{2} \mathrm{Se}_{3} / \mathrm{Au}$ & 374 & 26.4 & 51.0 & 5.0 \\
\hline $\mathrm{AZO} / \mathrm{CdS} / \mathrm{Sb}_{2} \mathrm{Se}_{3} / \mathrm{Au}$ & 374 & 25.8 & 51.1 & 4.9 \\
\hline $\mathrm{FTO} / \mathrm{CdSe} / \mathrm{Sb}_{2} \mathrm{Se}_{3} / \mathrm{Au}$ & 587 & 21.0 & 61.8 & 7.6 \\
\hline $\mathrm{AZO} / \mathrm{CdSe} / \mathrm{Sb}_{2} \mathrm{Se}_{3} / \mathrm{Au}$ & 586 & 20.5 & 61.8 & 7.4 \\
\hline $\mathrm{FTO} / \mathrm{ZnO} / \mathrm{Sb}_{2} \mathrm{Se}_{3} / \mathrm{Au}$ & 538 & 30.4 & 55.6 & 9.1 \\
\hline $\mathrm{AZO} / \mathrm{ZnO} / \mathrm{Sb}_{2} \mathrm{Se}_{3} / \mathrm{Au}$ & 538 & 29.8 & 55.7 & 8.9 \\
\hline $\mathrm{FTO} / \mathrm{V}_{2} \mathrm{O}_{5}{ }^{*} / \mathrm{Sb}_{2} \mathrm{Se}_{3} / \mathrm{Au}$ & 599 & 25.1 & 67.9 & 10.2 \\
$\mathrm{FTO} / \mathrm{V}_{2} \mathrm{O}_{5}{ }^{* *} / \mathrm{Sb}_{2} \mathrm{Se}_{3} / \mathrm{Au}$ & 593 & 20.1 & 67.8 & 8.1 \\
\hline $\mathrm{AZO} / \mathrm{V}_{2} \mathrm{O}_{5}{ }^{*} / \mathrm{Sb}_{2} \mathrm{Se}_{3} / \mathrm{Au}$ & & & 67.9 & 9.9 \\
$\mathrm{AZO} / \mathrm{V}_{2} \mathrm{O}_{5}{ }^{* *} / \mathrm{Sb}_{2} \mathrm{Se}_{3} / \mathrm{Au}$ & 599 & 24.5 & 67.8 & 7.9 \\
\hline
\end{tabular}

*Direct gap; ** Indirect gap

In the case of $\mathrm{V}_{2} \mathrm{O}_{5}$ the calculations were made considering the indirect and direct interband transitions [19]. According to the results, the following considerations can be made: (a) the conversion efficiency of solar cells is generally improved when the FTO is used as TCO, compared to AZO. The increase in efficiency is due to a slight increase in Jsc, which can be justified by the higher bandgap value of the FTO; (b) the device photovoltaic performance is enhanced replacing the CdS with the alternative layers, especially the $\mathrm{V}_{2} \mathrm{O}_{5}$. The improvement is caused by a significant increase in the Voc. The Voc is mainly influenced by two factors: the band alignment and defects densities in the interfaces and the bulk absorber. The bulk defect density in the $\mathrm{Sb}_{2} \mathrm{Se}_{3}$ layer was fixed in $10^{15} \mathrm{~cm}^{-3}$ for all simulations, in order to focus the attention on the factors that depend on the buffer layer selected. Then the discussion will be centered in the band alignment and interface defects density. The results reported in Table 4 were obtained using an interface defect density $10^{15} \mathrm{~cm}^{-2}$ in all cases. The idea is to evaluate first, the roll of band alignment. Following this criterion, in Figure 2 the band diagrams of the four solar cells are 
presented and the valence and conduction band offset (VBO and CBO respectively) are pointed. It is common to take the spike-like band offset as positive and cliff-like as negative. It was demonstrated in references [22-24] that negative $\mathrm{CBO}$ reduce the $\mathrm{Voc}$ and the interface recombination became more important. On the other hand, a positive $\mathrm{CBO}$ in the range of $0-0.4 \mathrm{eV}$ allows a good solar cell performance favoring the Voc and FF and maintaining the Jsc almost constant. For values beyond 0.4 the Jsc is seriously affected and the efficiency is drastically reduced. The Jsc is favored by a cliff-CBO. In this work, the best Voc and FF values correspond to the buffer layers with the best band alignment: $\mathrm{V}_{2} \mathrm{O}_{5}$ and CdSe with a CBOs of $0.16 \mathrm{eV}$ and $-0.05 \mathrm{eV}$ respectively. On the other hand, the CdS has the most negative $\mathrm{CBO}$ value and show the highest deficit of Voc. The solar cells with the worst band alignment between buffer and $\mathrm{Sb}_{2} \mathrm{Se}_{3}$ layers should be more affect by interface defects density.

In Figure 3 the electrical parameters versus interface defect density are shown. It can be seen how the Voc in solar cell with CdS and $\mathrm{ZnO}$ as buffer layers is more sensible to the increase of interface defects density. Notice that ZnO, have the higher VBO that acts as a barrier for holes diffusion throw the interface, lowering the recombination in the interface and increasing the electric field in the depletion region. This results in a lower deficit of Voc comparing with CdS ones. Taking account, that this buffer layers have the worst lattice mismatch (see Table 3) therefore special attention would be paid in the interface quality specially in the $\mathrm{CdS} / \mathrm{Sb}_{2} \mathrm{Se}_{3}$ interface. In the case of $\mathrm{CdSe}$, the high lattice mismatch is compensated with the good band alignment that reduces the impact of the interface recombination, maintaining the Voc almost constant. Due to $\mathrm{V}_{2} \mathrm{O}_{5}$ has the best band alignment the effect of interface defects on $\mathrm{Voc}$ is almost nulled. Also, this buffer layer has the best lattice mismatch then a low defect density is expected.

The Jsc depends on the bandgap, the interface defects and the thickness of the buffer layer. As can be seen in Figure $3 \mathrm{~b}$ ), the bandgap plays the most important role, been the cells with $\mathrm{ZnO}$ as buffer layer, the one that exhibits the best Jsc. A wide band gap allows a better response in the short wavelengths, improving the external quantum efficiency (see Figure 4) and therefore the Jsc. The CdS and $\mathrm{V}_{2} \mathrm{O}_{5}$ have similar band gaps but a cliff like $\mathrm{CBO}$ in the $\mathrm{CdS} / \mathrm{Sb}_{2} \mathrm{Se}_{3}$ interface favored the $\mathrm{Jsc}$ in this case. In all cases, an increase in the interface defect density implies an increase of recombination and consequently losses in Jsc.

As we have pointed out before, a good band alignment reduces the impact of interface recombination and significantly improve the Voc and the solar cell efficiency. In Figure $3 \mathrm{~d}$ it could be notice that the solar cells with buffer layers that have the best band alignment, are less affected by the recombination losses. Finally, the $\mathrm{V}_{2} \mathrm{O}_{5}$ shows the best performance as buffer layer due to the improve in $\mathrm{FF}$ and Voc resulting in the best efficiency behavior.

\subsection{Effect of bilayers on n-p device photovoltaic performance}

In the next step a bilayer is used as buffer layer in the n-p structure. The interdiffusion between CdS and $\mathrm{Sb}_{2} \mathrm{Se}_{3}$ is considered as a possible degradation mechanism in this solar cell. The diffusion of $\mathrm{Cd}$ towards to $\mathrm{Sb}_{2} \mathrm{Se}_{3}$ and $\mathrm{Se}$ and $\mathrm{Sb}$ towards $\mathrm{CdS}$ is a controversial discussion. The first hypothesis means that the 
$\mathrm{Cd}$ act as donor dopant of $\mathrm{Sb}_{2} \mathrm{Se}_{3}$ creating an additional rectifying junction in the spatial charge region [25]; while based on the second one process, the CdS is not a suitable emitter to partner $\mathrm{Sb}_{2} \mathrm{Se}_{3}$ due to $\mathrm{Se}$ diffusion, that contributes to the interface defects formation and compensation of donor states in CdS layer [26]. In reference [27] the CdSe was used with the intention to suppress the interdiffusion of Se across the interface. However, in this work no significant improvement in the efficiency was obtained. Considering the above-mentioned results, two bilayers were evaluated in the present work: CdS/CdSe and the $\mathrm{ZnO} / \mathrm{V} 205$. The last one was introduced since single-layers shown the best efficiency results and not contain $\mathrm{Cd}$. Table 5 list the electrical parameters for the solar cells using the bilayers as emitters. From these results, the fallowing is concluded: CdS/CdSe bilayers improve the electrical parameters respect to the $\mathrm{CdS}$ and $\mathrm{CdSe}$ single-layers and using a bilayer without $\mathrm{Cd}$ an ulterior increase in the efficiency was achieved. $\mathrm{A}$ best band alignment between $\mathrm{V}_{2} \mathrm{O}_{5}$ and $\mathrm{Sb}_{2} \mathrm{Se}_{3}$ and high bandgap of $\mathrm{ZnO}$ results in better Voc and Jsc values respectively compared with CdS-CdSe bilayer, then a best solar cell efficiency was obtained. Taking in to account that efficiency improvement in $0.5 \%$ for the records cells based in $\mathrm{Sb}_{2}(\mathrm{SSe})_{3}$ for $10 \%$ to $10.5 \%$ implied a technological effort, an increase from $5,0 \%$ (with CdS) to $11.6 \%$ (with $\mathrm{ZnO} / \mathrm{V}_{2} \mathrm{O}_{5}$ ) may justify adding another layer in the $\mathrm{n}-\mathrm{p}$ structures.

Table 5. J-V parameters for solar cells in n-p configurations with ETL-bilayers.

\begin{tabular}{|c|c|c|c|c|c|}
\hline Device structure (bilayer ETL) & $\begin{array}{l}\text { Voc } \\
(\mathrm{mV})\end{array}$ & $\mathrm{Jsc}\left(\mathrm{mA} / \mathrm{cm}^{2}\right)$ & FF (\%) & $\begin{array}{l}\text { h } \\
\text { (\%) }\end{array}$ & $\begin{array}{l}\text { 4.3. Effect of n-i-p structure } \\
\text { on device photovoltaic } \\
\text { performance. }\end{array}$ \\
\hline $\mathrm{FTO} / \mathrm{CdS}-\mathrm{CdSe} / \mathrm{Sb}_{2} \mathrm{Se}_{3} / \mathrm{Au}$ & 581 & 23.5 & 61.4 & 8.4 & As indicated above, the Voc \\
\hline $\mathrm{FTO} / \mathrm{ZnO}-\mathrm{V}_{2} \mathrm{O}_{5} / \mathrm{Sb}_{2} \mathrm{Se}_{3} / \mathrm{Au}$ & 603 & 28.4 & 67.7 & 11.6 & deficit of $0.7 \mathrm{eV}$ in antimony \\
\hline
\end{tabular}

parameter to be overcome. The Jsc and the FF reach their Shockley-Queisser (S-Q) limits faster than the Voc in this type of solar cells, which determines a lower Voc growth compared to efficiency increase. So, an increase in efficiency requires a decrease in the Voc deficit.

The n-i-p structure provides a more effective electric field to separate the photoexcited carriers, compared to the traditional $p$-n structure in substrate or superstrate configurations. The electric field responsible for charge separation is formed throughout the entire thickness of the absorber in the n-i-p structure, unlike the field created in the region of space charge, in the $p$-n junction. The n-i-p structure is formed adding a $\mathrm{Cu}_{2} \mathrm{O}$ layer (see Figure $1 \mathrm{f}$ ). In order to compare the impact of both structures on the properties of solar cells, Table 6 shows the electrical parameters of the structures using the $\mathrm{V}_{2} \mathrm{O}_{5}$ as $E T L$ in both cases. As can be seen, the efficiency value of $11 \%$ is reached in the $\mathrm{FTO} / \mathrm{V}_{2} \mathrm{O}_{5} / \mathrm{Sb}_{2} \mathrm{Se}_{3} / \mathrm{Cu}_{2} \mathrm{O} / \mathrm{Au}$ configuration. For this comparative analysis, the same thicknesses $(100 \mathrm{~nm})$ were set for the $\mathrm{ETL}, 50 \mathrm{~nm}$ for $\mathrm{Cu}_{2} \mathrm{O}$ and 500 $\mathrm{nm}$ for the absorber. The value of $10^{15} \mathrm{~cm}^{-2}$ was used for $\mathrm{Sb}_{2} \mathrm{Se}_{3} / \mathrm{Cu}_{2} \mathrm{O}$ interface defect density. In Figure 5 the dependences of $\mathrm{Voc}, \mathrm{Jsc}, \mathrm{FF}$, and on the $\mathrm{ETL} / \mathrm{Sb}_{2} \mathrm{Se}_{3}$ interface defects density are shown, for n-p and n-i-p structures. The increase in efficiency in n-i-p structure is due to the reduction in bulk 
recombination in the absorber layer resulting in a higher Voc and FF with respect to the $n-p$ structures. The Jsc was not improved by the addition of an HTL. In terms of interface defect density, small changes in Voc and FF are observed when defects increase. On the other hand, the Jsc is more affected by interface recombination in both cases. The good band alignment between $\mathrm{V}_{2} \mathrm{O}_{5}$ and $\mathrm{Sb}_{2} \mathrm{Se}_{3}$ determines that above a certain value of the interface defect density, the electrical parameters remain constant. In other words, the better the band alignment, the less the effect of the interfacial states on solar cell efficiency. Values of $10^{11} \mathrm{~cm}^{-2}$ was reported in [9] for $\mathrm{ZnO} / \mathrm{Sb}_{2} \mathrm{Se}_{3}$ interface, then value of $10^{12} \mathrm{~cm}^{-2}$ could be considering the optimal for both structures taking account that for lower values all parameters show saturation.

Table 6. J-V parameters for solar cells in n-p and n-i-p configurations using V2O5 as ETL

\begin{tabular}{|lllll|}
\hline Device structure & $\begin{array}{l}\text { Voc } \\
(\mathrm{mV})\end{array}$ & $\mathrm{Jsc}\left(\mathrm{mA} / \mathrm{cm}^{2}\right)$ & $\mathrm{FF}(\%)$ & $\begin{array}{l}\eta \\
(\%)\end{array}$ \\
\hline FTO $/ \mathrm{V}_{2} \mathrm{O}_{5} / \mathrm{Sb}_{2} \mathrm{Se}_{3} / \mathrm{Au}(\mathrm{n}-\mathrm{p})$ & 599 & 25.1 & 67.9 & 10.2 \\
\hline FTO $/ \mathrm{V}_{2} \mathrm{O}_{5} / \mathrm{Sb}_{2} \mathrm{Se}_{3} / \mathrm{Cu}_{2} \mathrm{O} / \mathrm{Au}(\mathrm{n}-\mathrm{i}-\mathrm{p})$ & 638 & 25.1 & 68.7 & 11.0 \\
\hline
\end{tabular}

Finally, the ETL and $\mathrm{Sb}_{2} \mathrm{Se}_{3}$ layer thicknesses were varied to evaluate the impact on solar cell performance. The $10^{12} \mathrm{~cm}^{-2}$ defect density value was used for $\mathrm{ETL} / \mathrm{Sb}_{2} \mathrm{Se}_{3}$ interface. In Figure 6 a contour plot of efficiency and $\mathrm{Voc} v \mathrm{~V}_{2} \mathrm{O}_{5}$ and $\mathrm{Sb}_{2} \mathrm{Se}_{3}$ thickness layer is shown for $\mathrm{n}$ - $\mathrm{p}$ and $\mathrm{n}$-i-p structures. A thicker $\mathrm{V}_{2} \mathrm{O}_{5}$ layer results in more absorption where there is not electric field to separate the photogenerated carriers, increasing recombination and deteriorating the Voc, and Jsc, also the FF by increasing the serial resistant and finally the solar cell efficiency. On the other hand, the increase of $\mathrm{Sb}_{2} \mathrm{Se}_{3}$ thickness first improve the solar cell efficiency and beyond certain value saturation occurs. The results can be explained based on three factors: the absorption of light, the series resistance and bulk recombination. Increasing the thickness more photons are absorbed, and more carrier are generated improving the Jsc and then efficiency. But the increase in Jsc is compensated by recombination, because of the carriers must travel a greater distance to reach the electrodes, and by series resistance that also increase with the layer thickness. As can be seen for absorber thickness higher than 0.6 high efficiencies could be achieve using $\mathrm{V}_{2} \mathrm{O}_{5}$ as emitter or ETL in n-p and n-i-p structures. In the case of $\mathrm{V}_{2} \mathrm{O}_{5}$ layer the idea is reduce the thickness as much as possible, but a thinner layer could create pinholes and short circuit the device, besides the technological limitation. Nevertheless for $70 \mathrm{~nm}$ of layer thickness efficiencies above the $14 \%$ in both cases could be achieved.

\section{Conclusion}

According to the results presented in this work the following conclusions are derived: 
The record efficiency achieved of $9.2 \%$ in $\mathrm{Sb}_{2} \mathrm{Se}_{3}$ solar cells can be improved by the following proposals: (a) the substitution of AZO for FTO as TCO and of CdS for $\mathrm{V}_{2} \mathrm{O}_{5}$ as ETL layer in the n-p structure. In the FTO $/ \mathrm{V}_{2} \mathrm{O}_{5} / \mathrm{Sb}_{2} \mathrm{Se}_{3} /$ Au configuration, an efficiency of $10.2 \%$ was obtained; (b) adding a second layer in the form of ETL-bilayer, the best combination turned out to be $\mathrm{ZnO} / \mathrm{V}_{2} \mathrm{O}_{5}$ with an ulterior increment in the efficiency of $11.6 \%$. This result must evaluate in terms of the experimental complexity. $\mathrm{ZnO}$ can be deposited by various methods. Between then, the pneumatic chemical spray it has proven to be a suitable technique. (c) The analysis of the n-i-p structure confirms the improvement of the electrical parameter that is more difficult to improve in this type of solar cells, that is, the Voc. Values greater than $600 \mathrm{mV}$ were obtained representing a substantial reduction of the Voc deficit. (d)The comparative study of the n-p structure in the FTO/ $\mathrm{V}_{2} \mathrm{O}_{5} / \mathrm{Sb}_{2} \mathrm{Se}_{3} / \mathrm{Au}$ configuration and the n-i-p in the FTO/ $\mathrm{V}_{2} \mathrm{O}_{5} / \mathrm{Sb}_{2} \mathrm{Se}_{3} / \mathrm{Cu}_{2} \mathrm{O} / \mathrm{Au}$ configuration, showed that by optimizing the layers thickness in both structures efficiencies above $14 \%$ could be achieved.(e) No significant increase in efficiency was obtained using n-i-p structure compared to $n-p$ ones, that justified the incorporation of additional layer. (f) It was demonstrated that interface recombination can be counteracted by a good band alignment. Finally, it is important to mention that absorber quality is critical if high efficiency wants to be reached. The bulk defect density, the ribbons orientation and doping in the $\mathrm{Sb}_{2} \mathrm{Se}_{3}$ material require especial attention. These results could be considered as a guide in the processing of planar solar cells of $\mathrm{Sb}_{2} \mathrm{Se}_{3}$ and a step in the purpose of maximize the efficiency to guarantee their future at industrial level.

\section{Declarations}

\section{Acknowledgements:}

The authors gratefully acknowledge to Dr. Marc Burgelman, University of Gent, Belgium, for providing the SCAPS simulation software. F Ayala-Mato and M. M. Nicolás-Marín acknowledges to CONACyT for the financial support to the respective PhD programs. O. Vigil Galán acknowledges the financial support under the project SIP-20201522, COFAA and EDI of IPN. M. Courel acknowledges financial support under the project PRODEP-NPTC (UDG-PTC-1523) and PRO-SNI from the University of Guadalajara.

\section{References}

[1] C. Chen, D.C. Bobela, Y. Yang, S. Lu, K. Zeng, C. Ge, B. Yang, L. Gao, Y. Zhao, M.C. Beard, J. Tang, Characterization of basic physical properties of Sb2Se3 and its relevance for photovoltaics, Front. Optoelectron. 10 (2017) 18-30. https://doi.org/10.1007/s12200-017-0702-z.

[2] K. Li, S. Wang, C. Chen, R. Kondrotas, M. Hu, S. Lu, C. Wang, W. Chen, J. Tang, 7.5\% n-i-p Sb2Se3 solar cells with CuSCN as a hole-transport layer, J. Mater. Chem. A. 7 (2019) 9665-9672. https://doi.org/10.1039/c9ta01773a.

[3] Z. Li, X. Liang, G. Li, H. Liu, H. Zhang, J. Guo, J. Chen, K. Shen, X. San, W. Yu, R.E.I. Schropp, Y. Mai, 9.2\%-Efficient Core-Shell Structured Antimony Selenide Nanorod Array Solar Cells, Nat. Commun. 10 
(2019) 1-9. https://doi.org/10.1038/s41467-018-07903-6.

[4] C. Chen, J. Tang, Open-Circuit Voltage Loss of Antimony Chalcogenide Solar Cells: Status, Origin, and Possible Solutions, ACS Energy Lett. 5 (2020) 2294-2304.

https://doi.org/10.1021/acsenergylett.0c00940.

[5] A. Mavlonov, T. Razykov, F. Raziq, J. Gan, J. Chantana, Y. Kawano, T. Nishimura, H. Wei, A. Zakutayev, T. Minemoto, X. Zu, S. Li, L. Qiao, A review of Sb2Se3 photovoltaic absorber materials and thin-film solar cells, Sol. Energy. 201 (2020) 227-246. https://doi.org/10.1016/j.solener.2020.03.009.

[6] P. Roy, N. Kumar Sinha, S. Tiwari, A. Khare, A review on perovskite solar cells: Evolution of architecture, fabrication techniques, commercialization issues and status, Sol. Energy. 198 (2020) 665-688. https://doi.org/10.1016/j.solener.2020.01.080.

[7] R. Tang, X. Wang, W. Lian, J. Huang, Q. Wei, M. Huang, Y. Yin, C. Jiang, S. Yang, G. Xing, S. Chen, C. Zhu, X. Hao, M.A. Green, T. Chen, Hydrothermal deposition of antimony selenosulfide thin films enables solar cells with $10 \%$ efficiency, Nat. Energy. 5 (2020) 587-595. https://doi.org/10.1038/s41560-020-06523.

[8] G. Li, Z. Li, X. Liang, C. Guo, K. Shen, Y. Mai, Improvement in Sb 2 Se 3 Solar Cell Efficiency through Band Alignment Engineering at the Buffer/Absorber Interface, ACS Appl. Mater. Interfaces. 11 (2019) 828-834. https://doi.org/10.1021/acsami.8b17611.

[9] L. Wang, D.B. Li, K. Li, C. Chen, H.X. Deng, L. Gao, Y. Zhao, F. Jiang, L. Li, F. Huang, Y. He, H. Song, G. Niu, J. Tang, Stable 6\%-efficient Sb2Se3 solar cells with a ZnO buffer layer, Nat. Energy. 2 (2017) 1-9. https://doi.org/10.1038/nenergy.2017.46.

[10] L. Guo, C. Grice, B. Zhang, S. Xing, L. Li, X. Qian, F. Yan, Improved stability and efficiency of CdSe/Sb2Se3 thin-film solar cells, Sol. Energy. 188 (2019) 586-592.

https://doi.org/10.1016/j.solener.2019.06.042.

[11] Z.Q. Li, M. Ni, X.D. Feng, Simulation of the Sb2Se3 solar cell with a hole transport layer, Mater. Res. Express. 7 (2019). https://doi.org/10.1088/2053-1591/ab5fa7.

[12] Y. Cao, X. Zhu, H. Chen, X. Zhang, J. Zhou, Z. Hu, J. Pang, Towards high efficiency inverted Sb2Se3 thin film solar cells, Sol. Energy Mater. Sol. Cells. 200 (2019).

https://doi.org/10.1016/j.solmat.2019.109945.

[13] S.R. Al Ahmed, A. Sunny, S. Rahman, Performance enhancement of Sb2Se3 solar cell using a back surface field layer: A numerical simulation approach, Sol. Energy Mater. Sol. Cells. 221 (2021) 110919. https://doi.org/10.1016/j.solmat.2020.110919.

[14] F. Ayala-Mató, O. Vigil-Galán, D. Seuret-Jiménez, M. Courel, S. Fernández, Evaluation of Cd 1-x Zn $x \mathrm{~S}$ as electron transport layer in superstrate and inverted configurations of $\mathrm{Sb} 2 \mathrm{Se} 3$ solar cells with n-i- 
p structure , Semicond. Sci. Technol. 36 (2021) 015016. https://doi.org/10.1088/1361-6641/abc7d0.

[15] M. Burgelman, P. Nollet, S. Degrave, Modelling polycrystalline semiconductor solar cells, Thin Solid Films. 361 (2000) 527-532. https://doi.org/10.1016/S0040-6090(99)00825-1.

[16] M. Gloeckler, A.L. Fahrenbruch, J.R. Sites, Numerical modeling of CIGS and CdTe solar cells: setting the baseline, 3rd World Conf. OnPhotovoltaic Energy Conversion, 2003. Proc. 1 (2003) 491-494. https://doi.org/10.1002/0471743984.vse8888.

[17] S. Adachi, Optical Constants of Crystalline and Amorphous Semiconductors. Numerical Data and Graphical Information, Springer Science+Busines Media, LLC, 1999. https://doi.org/DOI 10.1007/978-14615-5247-5.

[18] K.A. Aly, Discussion on the interrelationship between structural, optical, electronic and elastic properties of materials, J. Alloys Compd. 630 (2015) 178-182.

https://doi.org/10.1016/j.jallcom.2014.10.079.

[19] M. Kang, S.W. Kim, Y. Hwang, Y. Um, J.W. Ryu, Temperature dependence of the interband transition in a V2O 5 film, AlP Adv. 3 (2013). https://doi.org/10.1063/1.4808021.

[20] C. Malerba, F. Biccari, C. Leonor Azanza Ricardo, M. D’Incau, P. Scardi, A. Mittiga, Absorption coefficient of bulk and thin film Cu2O, Sol. Energy Mater. Sol. Cells. 95 (2011) 2848-2854. https://doi.org/10.1016/j.solmat.2011.05.047.

[21] S.C. Jain, A.H. Harker, R.A. Cowley, Misfit strain and misfit dislocations in lattice mismatched epitaxial layers and other systems, Philos. Mag. A Phys. Condens. Matter, Struct. Defects Mech. Prop. 75 (1997) 1461-1515. https://doi.org/10.1080/01418619708223740.

[22] S. Sharbati, J.R. Sites, Impact of the band offset for $n-Z n(0, S) / p-C u(I n, G a) S e 2$ solar cells, IEEE J. Photovoltaics. 4 (2014) 697-702. https://doi.org/10.1109/JPHOTOV.2014.2298093.

[23] T. Minemoto, Y. Hashimoto, T. Satoh, T. Negami, H. Takakura, Y. Hamakawa, Cu(In,Ga)Se2 solar cells with controlled conduction band offset of window/Cu(In,Ga)Se2 layers, J. Appl. Phys. 89 (2001) 83278330. https://doi.org/10.1063/1.1366655.

[24] T. Minemoto, T. Matsui, H. Takakura, Y. Hamakawa, T. Negami, Y. Hashimoto, T. Uenoyama, M. Kitagawa, Theoretical analysis of the effect of conduction band offset of window/CIS layers on performance of CIS solar cells using device simulation, Sol. Energy Mater. Sol. Cells. 67 (2001) 83-88. https://doi.org/10.1016/S0927-0248(00)00266-X.

[25] Y. Zhou, Y. Li, J. Luo, D. Li, X. Liu, C. Chen, H. Song, J. Ma, D.J. Xue, B. Yang, J. Tang, Buried homojunction in $\mathrm{CdS} / \mathrm{Sb} 2 \mathrm{Se} 3$ thin film photovoltaics generated by interfacial diffusion, Appl. Phys. Lett. 111 (2017). https://doi.org/10.1063/1.4991539. 
[26] R.E. Williams, Q.M. Ramasse, K.P. McKenna, L.J. Phillips, P.J. Yates, O.S. Hutter, K. Durose, J.D. Major, B.G. Mendis, Evidence for Self-healing Benign Grain Boundaries and a Highly Defective Sb2Se3-CdS Interfacial Layer in Sb2Se3 Thin-Film Photovoltaics, ACS Appl. Mater. Interfaces. 12 (2020) 2173021738. https://doi.org/10.1021/acsami.0c03690.

[27] L. Guo, C. Grice, B. Zhang, S. Xing, L. Li, X. Qian, F. Yan, Improved stability and efficiency of CdSe/Sb 2 Se 3 thin-film solar cells, (2019). https://doi.org/10.1016/j.solener.2019.06.042.

\section{Figures}

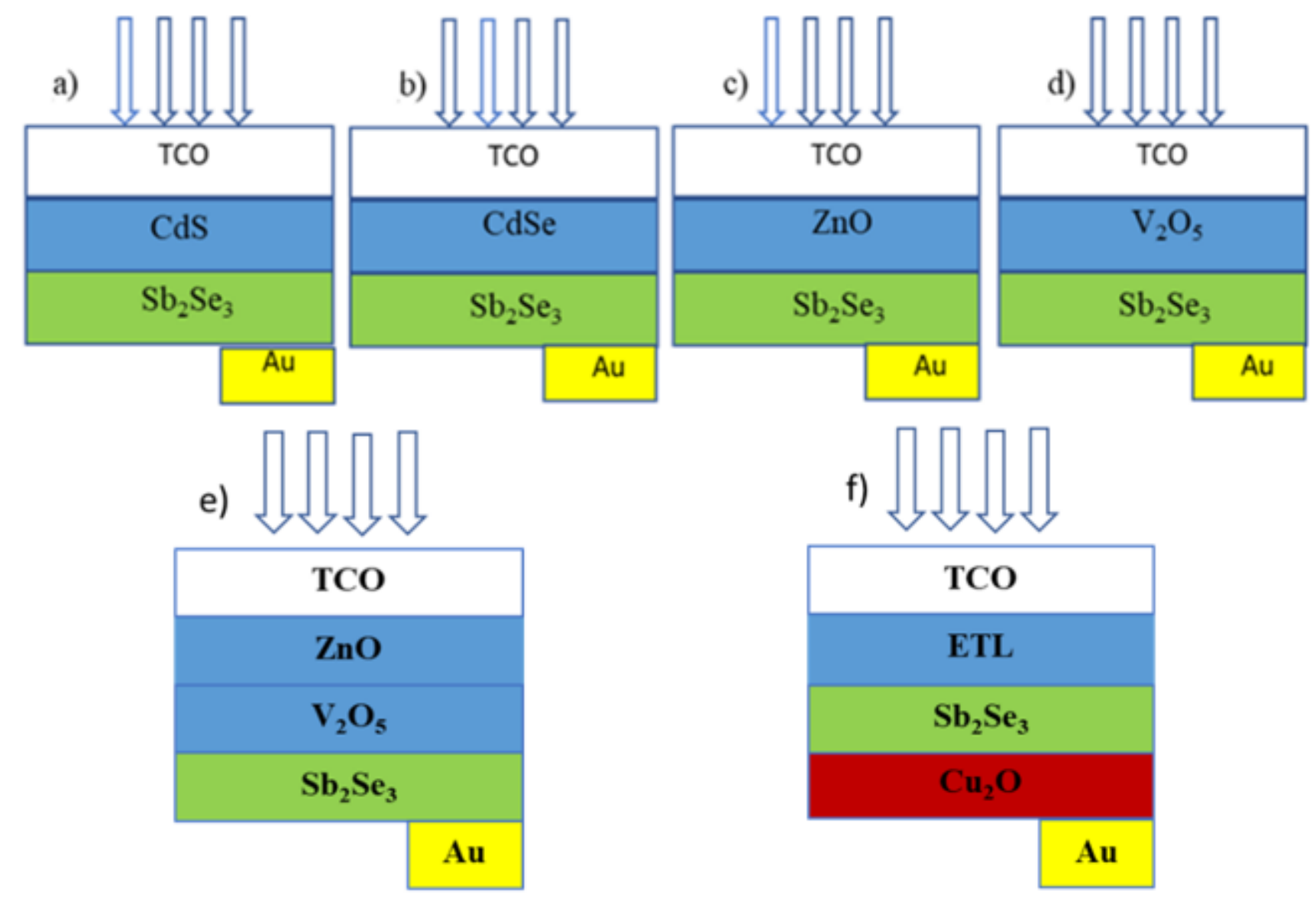

\section{Figure 1}

Solar cell structures simulated in this works. 
a)

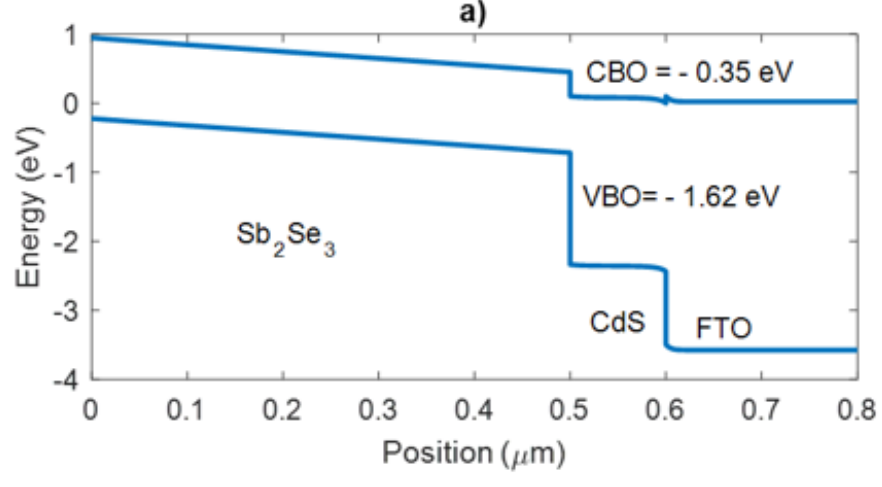

c)

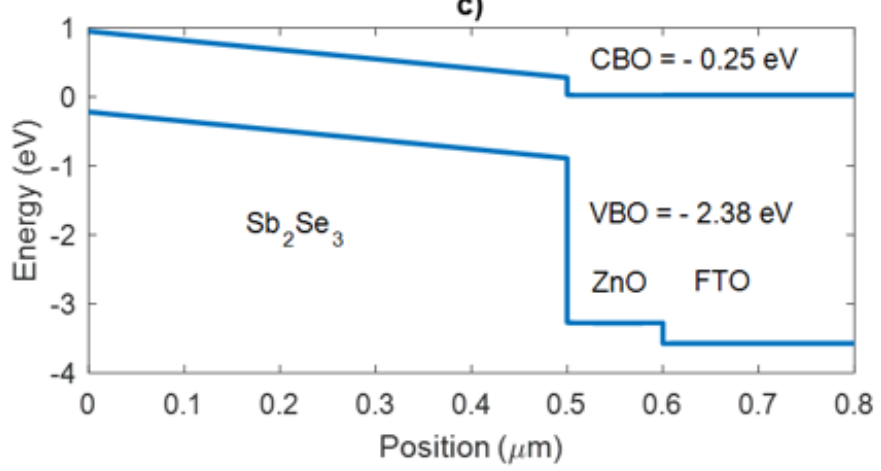

b)

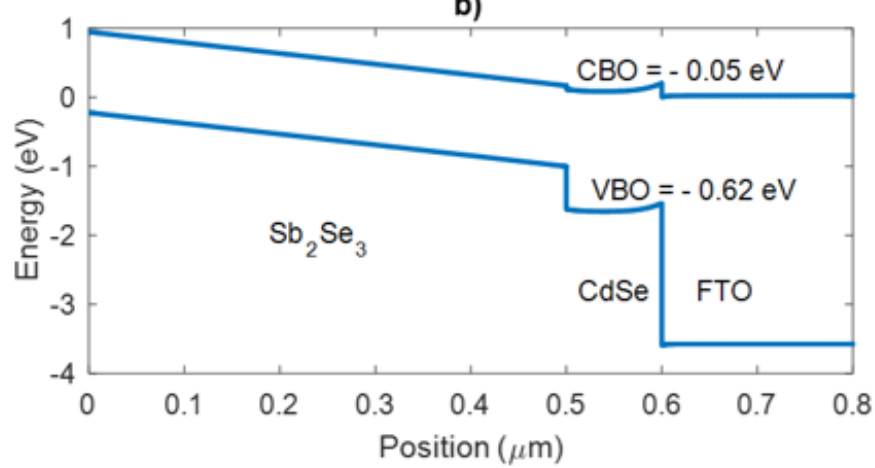

d)

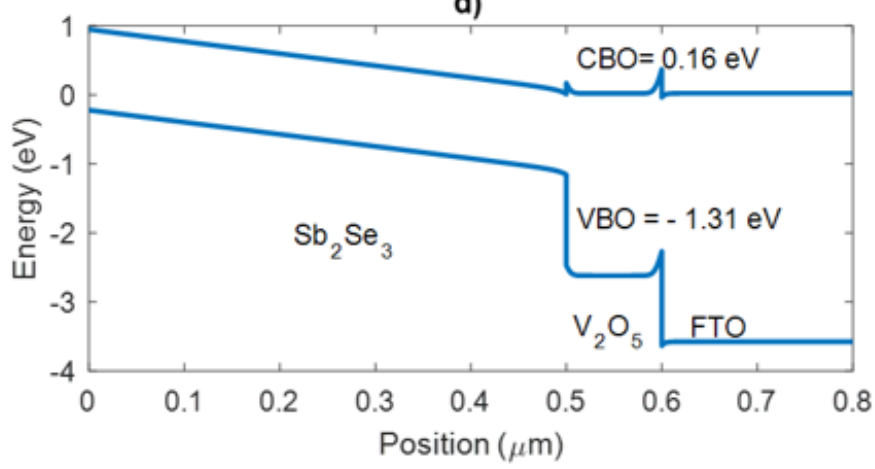

Figure 2

Band diagram for solar cell in n-p structure. 
a)

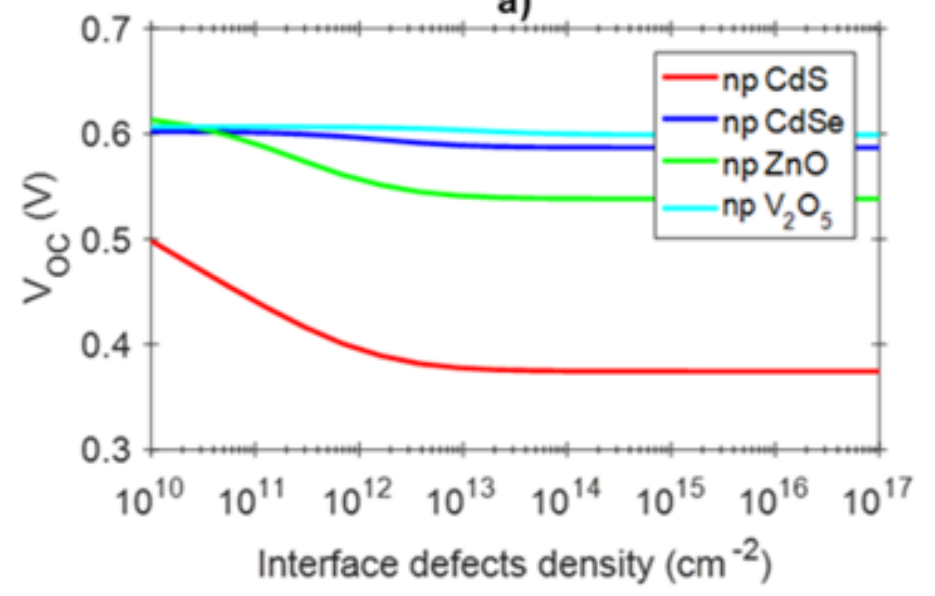

c)

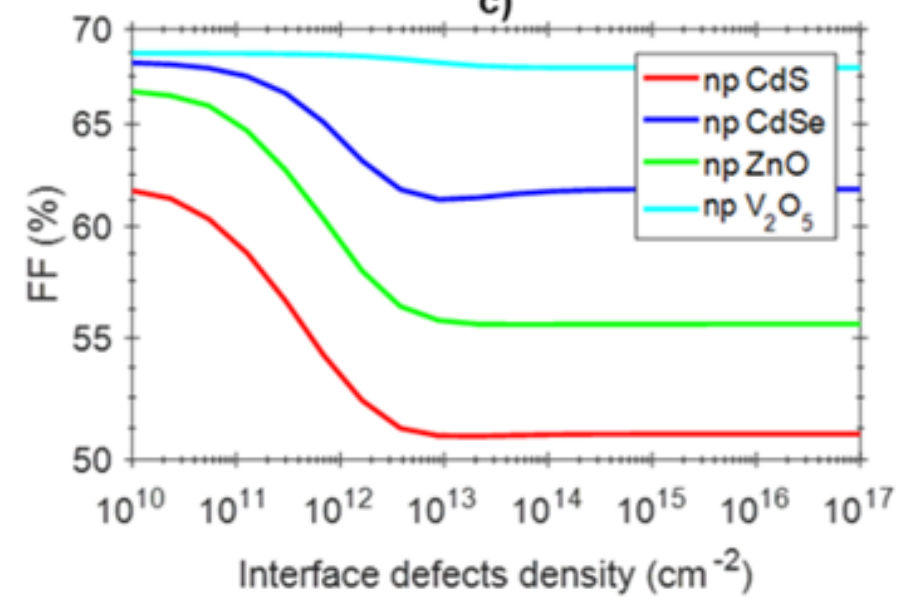

b)

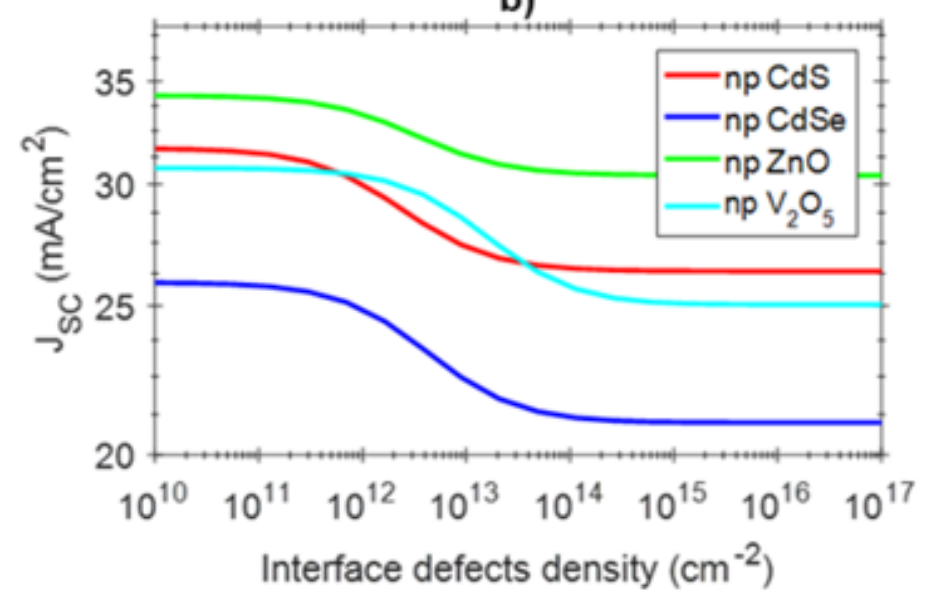

d)

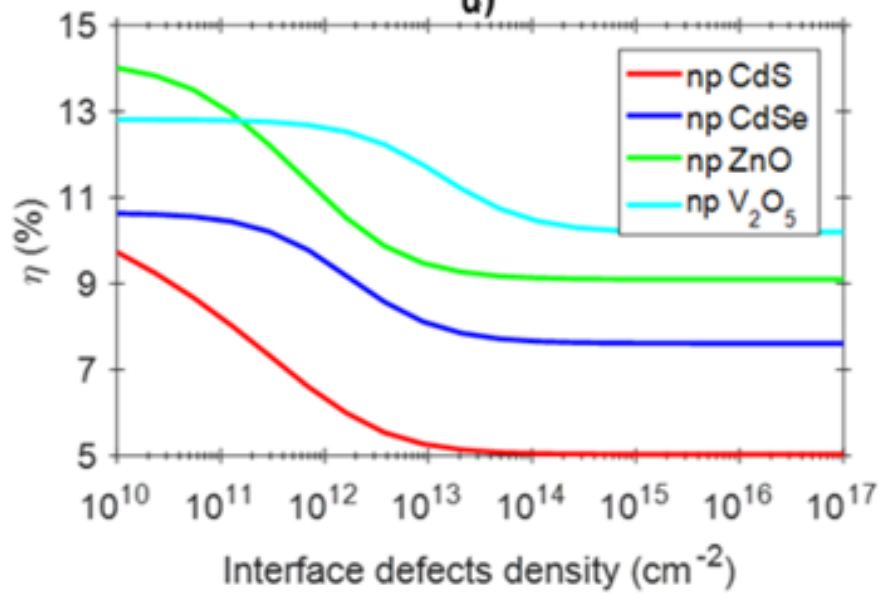

Figure 3

Electrical parameters versus interface defects density for each solar cell in n-p structure using different buffer layers. 


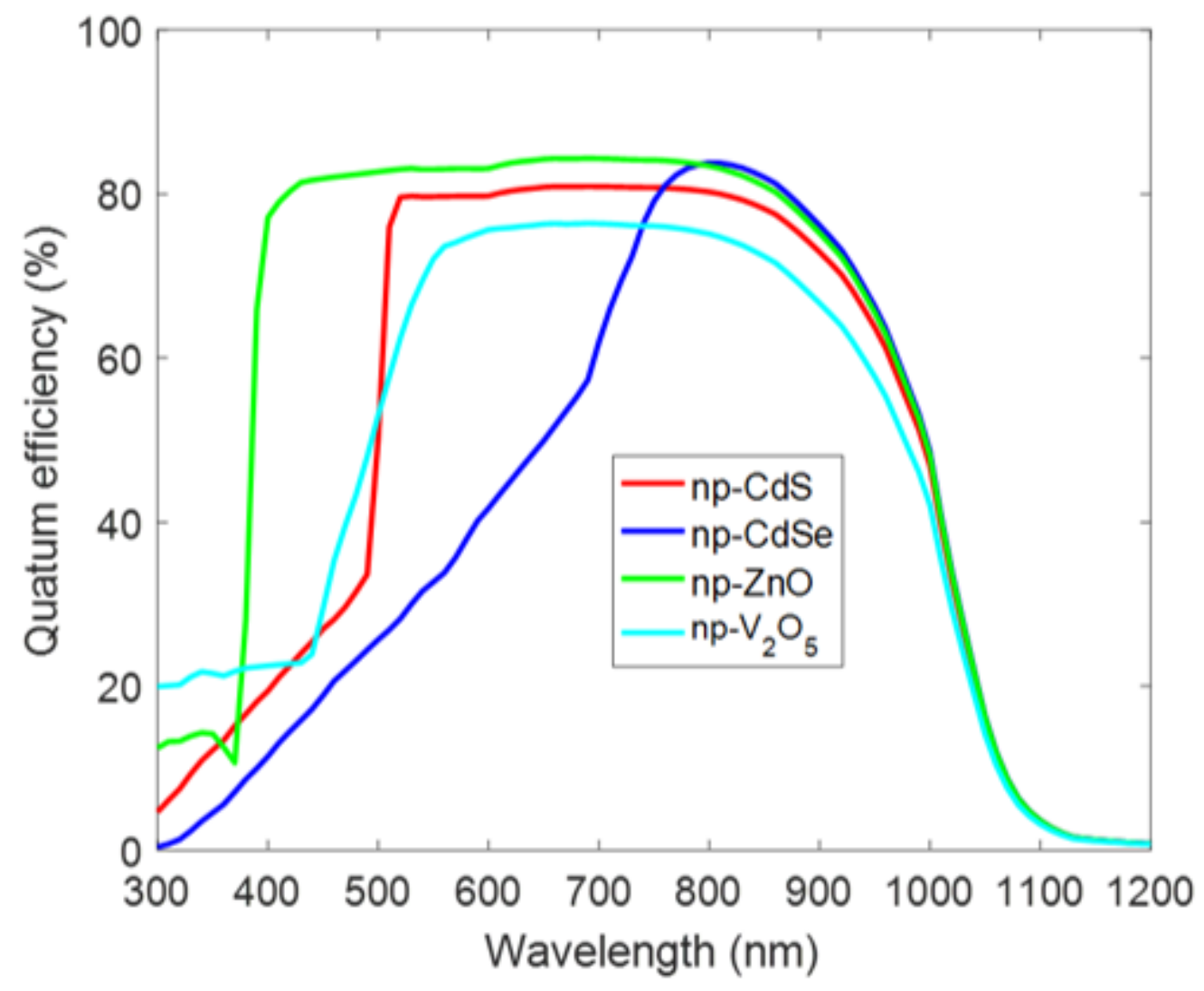

Figure 4

External quantum efficiency for solar cells in n-p structure with single buffer layer.

a)

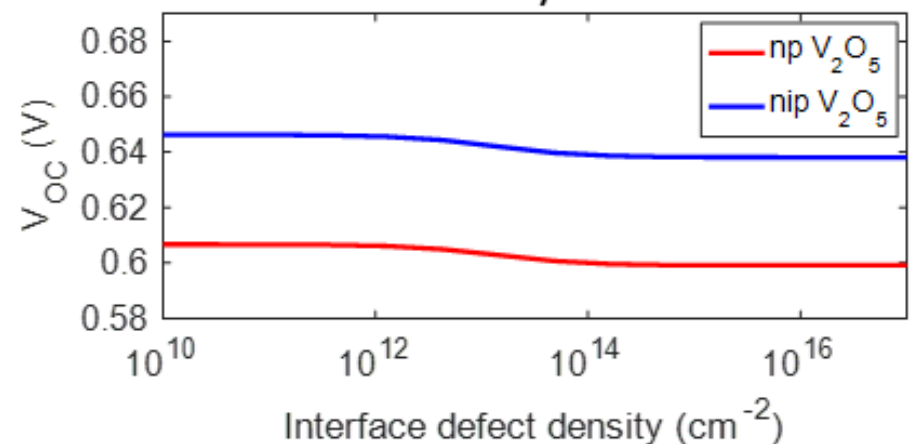

c)

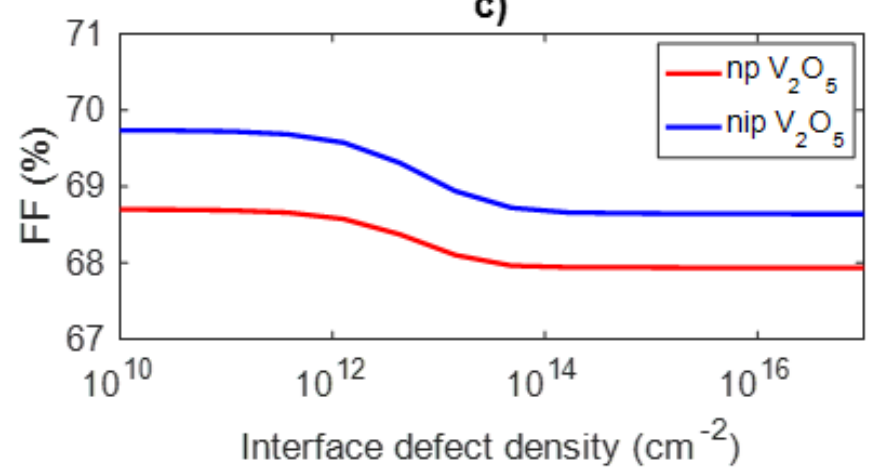

b)

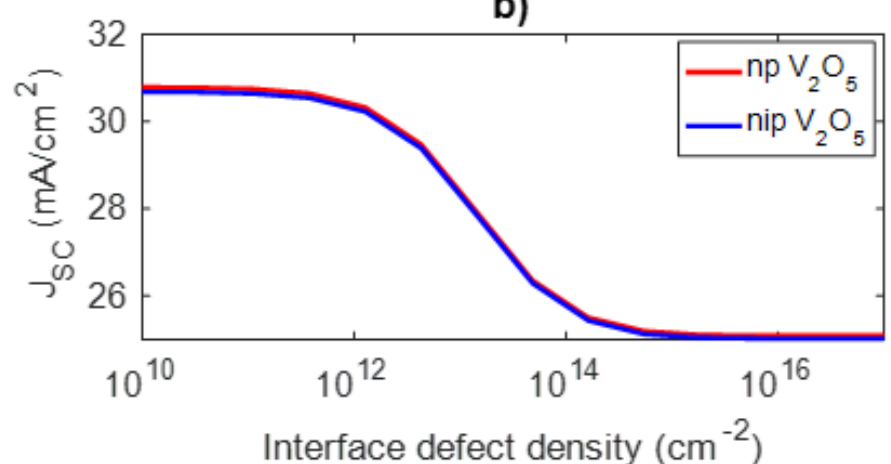

d)

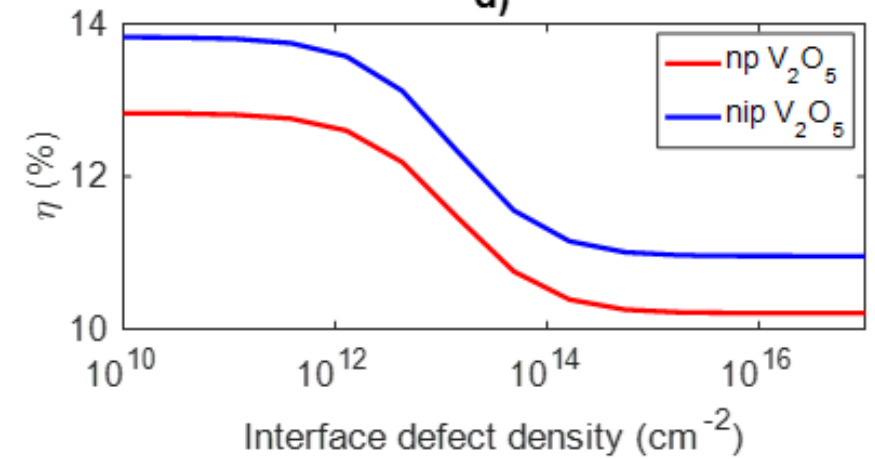

Figure 5 
Electrical parameters vs interface defect density in n-p and n-i-p structures
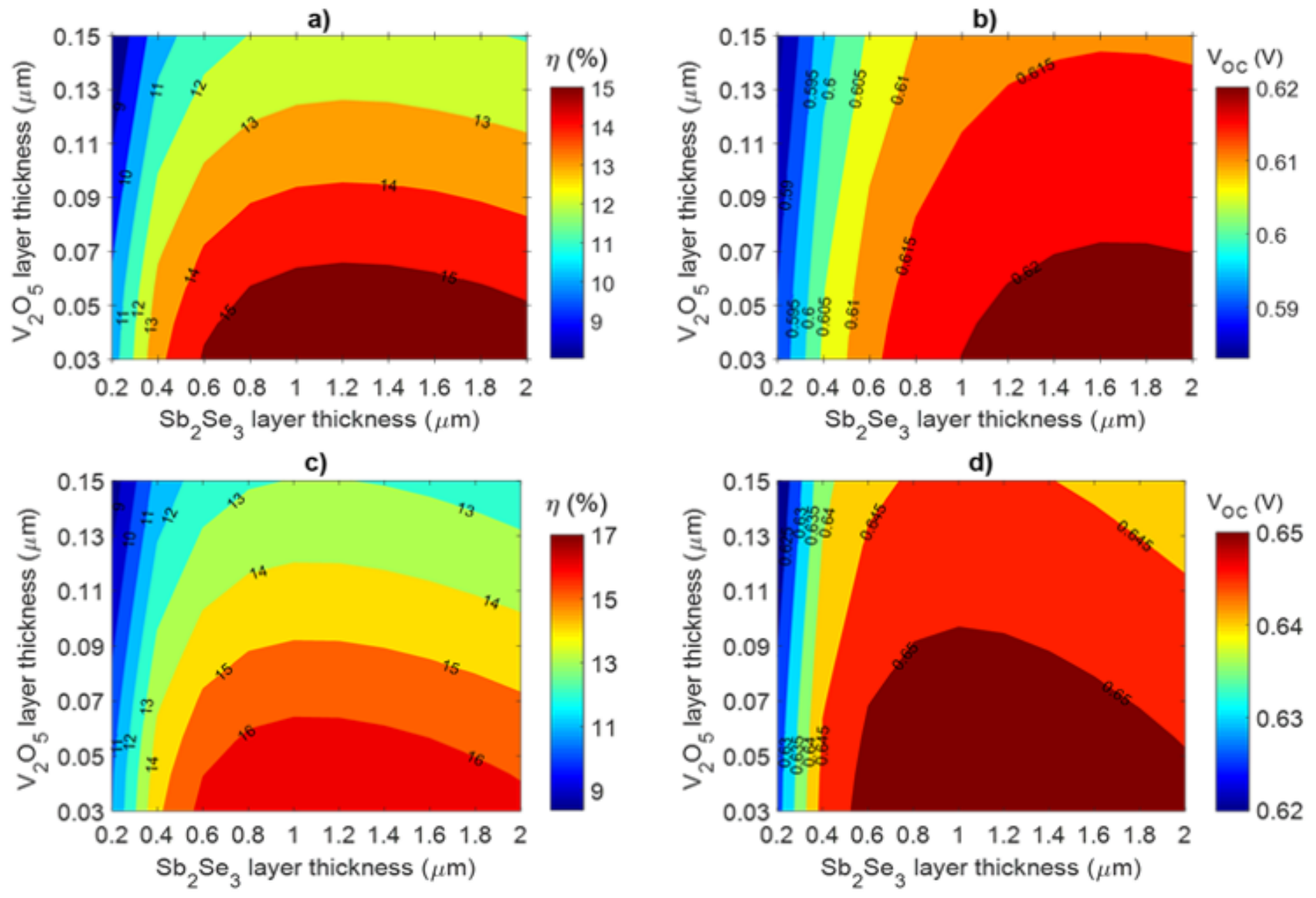

\section{Figure 6}

Contour plot for solar cell efficiency and Voc vs V2O5 and Sb2Se3 thickness: a) and b) for n-p structure, c) and d) for n-i-p structure. 